\title{
ARTICLE PLACES Of ENUNCIATION AND DISPUTES Of MEANING OF JOURNALISTIC WORK IN ALTERNATIVE ARRANGEMENTS TO MEDIA CORPORATIONS
}

Copyright (C) 2019 SBPjor / Associação Brasileira de Pesquisadores em Jornalismo

\section{RAFAEL GROHMANN}

Universidade Federal do Rio de Janeiro, Rio de Janeiro (RJ), Brazil ORCID: 0000-0003-1063-8668

MICHELLE ROXO

FIAM-FAAM - Centro Universitário, São Paulo (SP), Brazil

ORCID: 0000-0002-1344-3412

ANA FLÁVIA MARQUES

Universidade de São Paulo, São Paulo (SP), Brazil

ORCID: 0000-0002-3447-3506

DOI: 10.25200/BJR.v15n1.2019.1079

\begin{abstract}
The paper intends to analyze how "alternative arrangements to media corporations" name their work activities in relation to journalism and express certain ethos in their presentation texts (official websites) - taken here as a corpus of analysis. Considering a set of initiatives of this nature in São Paulo, it seeks to identify the different places of enunciation of these arrangements, as well as the disputes of meaning engendered in these spaces. It defines operational criteria to visualize the presence/absence of identification marks (with journalism) and of differentiation (in relation to the meaning of journalism enunciated by the subjects), from the construction of two categories of analysis, classified as "markers of journalistic praxis" and "journalism qualifiers".
\end{abstract}

Key words: Alternative arrangements. Enunciation. Journalism. Meaning disputes. Work.

\section{LUGARES DE ENUNCIACÃO E DISPUTAS DE SENTIDO EM RELACÃO AO TRABALHO JORNALÍSTICO EM ARRANJOS ALTERNATIVOS ÀS CORPORAÇÕES DE MÍDIA}

RESUMO - O artigo pretende analisar como "arranjos econômicos alternativos às corporações de mídia" nomeiam suas atividades de trabalho em relação ao jornalismo e manifestam determinados ethos em seus textos de apresentação (sites oficiais) - tomados, 
aqui, como corpus de análise. Considerando um conjunto de iniciativas desta natureza em São Paulo, procura identificar os diferentes lugares de enunciação destes arranjos, bem como as disputas de sentido engendradas nestes espaços. Define critérios operacionais para visualizar a presença/ausência de marcas enunciativas de identificação (com o jornalismo) e de diferenciação (em relação ao sentido de jornalismo enunciado pelos sujeitos), a partir da construção de duas categorias de análise, classificadas como "marcadores de práxis jornalísticas" e "qualificadores de jornalismo".

Palavras-chave: Arranjos alternativos. Enunciação. Jornalismo. Disputas de sentido. Trabalho.

\section{LUGARES DE ENUNCIACIÓN Y DISPUTAS DE SENTIDO EM RELACIÓN AL TRABAJO PERIODÍSTICO EN ARREGLOS ALTERNATIVOS A LAS CORPORACIONES DE MEDIOS}

RESUMEN - El artículo pretende analizar cómo "arreglos económicos alternativos a las corporaciones de medios" nombra sus actividades de trabajo en relación al periodismo y manifiestan determinados ethos en sus textos de presentación (sitios oficiales) - tomados aquí como corpus de análisis. Considerando un conjunto de iniciativas de esta naturaleza en São Paulo, busca identificar los diferentes lugares de enunciación de estos arreglos, así como las disputas de sentido engendradas en estos espacios. Define criterios operacionales para visualizar la presencia/ausencia de marcas enunciativas de identificación (con el periodismo) y de diferenciación (en relación al sentido de periodismo enunciado por los sujetos) a partir de la construcción de dos categorías de análisis, clasificadas como "marcadores de praxis periodística" y "calificadores de periodismo".

Palabras clave: Arreglo alternativo. Enunciación. Periodismo. Disputas de sentido. Trabajo.

\section{Introduction}

Starting with the protests in June 2013 - when Mídia Ninja gained media publicity (Peruzzo, 2013; Waltz, 2017) - the rise of "alternative" or "independent" forms of journalism has caught the eye of those in journalism research (Ramos \& Spinelli, 2015; Figaro \& Nonato, 2017; Reis, 2017; Assis et al., 2017; Carvalho \& Bronosky, 2017). New actors and production models, connected through networks, express forms of organization which do not follow the ones used by leading newsrooms. They are powered by technological advancements which lead to changes in the way information is consumed and produced. This phenomenon takes place in a scenario characterized by job insecurity (Figaro, Nonato \& Grohmann, 2013; Mick \& Lima, 2013) and a reduction in the number of formal jobs in major newsrooms due to restructuring processes and flexible work relations which affect many sectors, journalism included. 
This article is part of an investigation and is an integral part of the collective study called "Communication relations and the work conditions of journalists in economic arrangements alternative to media corporations". This study started in 2016 and its extensive methodology is explored in Figaro, Nonato \& Kinoshita (2017). A tentative definition' of "arrangements" comes from "economic arrangements", which are "networks of production which lack developed connections among agents needed in order to characterize them as systems" (Suzigan, 2004, p. 454). Then we have "local production arrangements" which are "territorial networks of economic, political and social agents - focused on a specific set of economic activities - that have connections, although they are still developing" (Suzigan, 2004, p. 546). This is how the modes of work organization look. We use the nomenclature "alternative arrangements to media corporations" to describe arrangements that (a) are not individual projects, (b) project a work perspective, (c) are present in digital media and (d) are not a corporation or a "traditional" media conglomerate.

We set out to map 73 initiatives of this nature in the city of São Paulo (an economic and media hub in Brazil) and focused our analysis on a specific area of research: the places of enunciation for journalism and journalist work on the official sites of these vehicles. How do these texts enunciate their activities and where is their place in relation to journalism? What are the disputes of meaning that take shape in this process and how do they relate to qualification/ differentiation strategies of the journalistic practices in these spaces?

\section{Enunciation and disputes of meaning}

Our corpus is comprised of journalistic texts from the official online sections of "Who We Are" or "About". These texts are part of a series of language activities related to work, particularly journalistic work. The "work discussions" provide an understanding of the job who speaks, how they speak and with what values - which then helps us identify "the modalities circulating around the 'language of work' and how this language is formed by the collective or the collective network" (Nouroudine, 2002, p. 26).

The enunciations in the texts are mostly part of stable discursive formations which are based on social practices in the field 
of journalism. As Fairclough states (2008, p. 93) in his concept of text, discourse practice and social practice, "the discursive constitution of society does not originate from the free ideas in people's heads, it comes from a social practice which is firmly rooted in material and concrete social structures". Consequently, the discourses are connected to modes of existence in the world.

Defining "who we are" means marking a place in the world, with its identifications and distinctions, uncovering the identities (ethe) in discourse - described by Aristotle (1998) and echoed in Barthes (2001) and Maingueneau (2008) as: "Ethos is, in its proper sense, a connotation: the orator enunciates information and, at the same time, says: I am this, not that" (Barthes, 2001, p. 78).

Fiorin (1994) reminds us that within ethos there is a discursive construction of both the "self" and the "other", without which there is no meaning. The discursive subject "represents, recognizes itself as having a certain identity inasmuch as it interacts with other discourses, it is in dialogue with them" (Nagamine, 2012, p. 26). This leads us to the concept of "dialogism" (Bakhtin, 2003), in that "the speaker is not Adam, and for this reason the object of its discourse becomes, ultimately, the point where the opinions of speakers meet" (Bakhtin, 2003, p. 213). In this regard, discourses are part of history, marking their place while in dialogue with other discourses (Baccega, 1995).

As Bakhtin states (2010), words are alive in language, they "stress value" or "stress appreciation"; values being defined as "ideological threads" that weave meaning. Thus, when we choose one word over another we are agreeing with certain discourses and disagreeing with others (reflection and refraction) that are a part of dialogism: "the self, reflected in the meaning, does not only reflect itself, but also refracts itself" (Bakhtin, 2010, p. 47). It is located ahead of disputes of meaning in any field - in the places of enunciation.

The ethos present in discourse and its dialogical relationships of values manifests its place of enunciation through enunciation marks. According to Baccega (1998, p. 95), "within enunciation lie the marks of the life conditions of a group, or a social class, which give rise to a greater or lesser abstract of greater or lesser generalization in the use of the word". They are basically evidence of subjects engaged in discourse. Ducrot \& Todorov (1988, p. 83) understand enunciation as "the act by which enunciations, phrases, sequences, etc. are realized, made by a particular speaker in specific 
spatial and temporal circumstances". It is a "linguistic stage logically presupposed by the existence of the speaker" (Fiorin, 2004, p. 70) which reveal texts in movement, in praxis.

Analyzing an ethos reveals its place of enunciation, the place where meanings are produced and debated. They are debated because, as Bakhtin (2010) reminds us about refraction, language is not a land of just consensus, but also of debate. Thus, contradictions and conflicts manifest, materialize and summarize in discourse.

These debates of meaning that come out of places of enunciation and their discursive marks are "struggle for classification" or "classification struggles", terms used by Bourdieu (1996; 2008) to symbolize struggles - that also come from enunciation - waged in a certain field to present a legitimate vision of the social world.

What is at stake within these struggles is the discursive production of meaning on the process of identifying/belonging to the field, as well as principles for assessing/recognizing producers and products as legitimate. "It is the struggle itself which makes history in the field", summarized by Bourdieu ${ }^{2}$ (1996, p.181). Bourdieu says that these symbolic struggles are also associated to different strategies which may ensure accumulation of capital particular to agents. To exist socially in a field that produces means being different, building a "name" that producers in this space will recognize. For instance, this tends to make newcomers interested in the break and the "ageing" of certain practices and modes of conceiving the activity: while establishing the "new", they seek symbolically more advantageous positions, already dominated or unrecognized within the relational logic that move the stakes of the game (Bourdieu, 1996). Therefore, and according to the terms in this interpretative plan, to think of journalism as a field means being aware of the principles of hierarchy, of the logics of differentiation and belonging mobilized by agents, as well as the "invention" and/or update of positions and oppositions that drive the internal struggles and redefine the actual limits of space (and of what journalism is). These are symbolic struggles that appear to become even more complex with the emergence of these new productive arrangements, creating strategies of legitimacy and belonging in journalism.

In this article we focused on mapping out different places of enunciation for alternative economic arrangements and the disputes of meaning that occur within these places. Of interest to us is how the 
arrangements express "modes of journalism" and "modes of being a journalist" (Grohmann, 2017b), and how, in its ethe, the journalism praxis is naturalized or classified, marked and qualified in dialogic relationships, revealing meanings of work and professionalism in journalism, as well as meanings of identity.

\section{Methodology}

We built up the research corpus for "Communication relations and the work conditions of journalists in economic arrangements alternative to media corporations" by starting with a mapping carried out by the Public Agency published in 2016 under the title The map of independent journalism. As the text explains, initiatives were selected according to the following criteria: they had to be organizations which were born online; they could not be associated with large media groups, political groups, organizations or companies; "they produce journalistic content first"; and they were characterized as collective projects (for example, individual bloggers were not included in the survey) (Pública, 2017). We also looked at initiatives selected by the agency as well as those recommended by readers, which are available on the Pública site - one of the arrangements that make up our corpus analysis. Other initiatives were nominated and added to our data banks through the snowball technique (Baldin \& Munhoz, 2011 ) and through internet searches based on the following criteria: the collective nature of the arrangement, self-defined journalists and disconnection from large media groups. Our initial sampling (nonstatistical and exploratory) finished in June 2017 with a total of 183 media outlets in Brazil, 73 of which in São Paulo (Figaro, Nonato \& Kinoshita, 2017). This methodological plan is the fruit of a collective construction project which we continually reviewed as we advanced through the stages of research and refined our analysis tools for cross-referencing with the empirical object.

As stated earlier, the corpus is made up of texts from the 73 initiatives from São Paulo and follow the overall research plan with the goal of (a) mapping out the initiatives in these enunciations that identify (or not) with journalism; (b) defining operational criteria for visualizing marks of identification (with journalism) and differentiation (in regards to the meaning of journalism enunciated by subjects in their respective spaces). In order to do this, we built 
two categories of analysis which we called marks of journalistic praxis and qualifiers of journalism. The first category allowed us to find key words in the texts associated to a "grammar" historically rooted in journalism and associated to a set of elements (discursive/ operational) socially asserted/attributed to this field of production. They are references to a kind of knowledge (of procedure, of narration) that shapes journalistic competence (Traquina, 2013). Thus, even though the subjects have not directly used the word journalism or the word journalists to define their position in these texts, the expression of them allows us to make connections of belonging and/or identification with the journalistic praxis. Story, news, interviews and verification are examples of the kinds of words expressed.

The second category, qualifiers of journalism, allowed us to observe the recurrence of differentiation principles in these spaces as pertaining to the perspectives and concepts of journalism. We were interested in identifying traits triggered by these initiatives to qualify how journalism is practiced there (and produce a difference in relation to "other" possible perspectives).

In relation to these qualifiers, we identified two recurring main principles of differentiation. The first is specialization or association to a "territory" and public spheres (cultural journalism, community journalism, Latin American journalism). The second is associated to the strength of these texts to trigger distinctive traits of the perspective of journalism adopted by these initiatives. Examples of these qualifier expressions are "counter-hegemonic narrative", "nonprofit journalism in the name of independence", "quality journalistic production", "journalism established in the report”, "journalism critical and alternative to large media conglomerates", "human, humanized and humanizing journalism", and others.

The practical part of this study was conducted by putting together a spreadsheet of the 73 initiatives, the texts collected from the arrangement sites, and columns representing the categories mentioned above. The spreadsheet was then filled with information gathered from text analysis, which used theoretical discussion as a basis for including places of enunciation as a form of discursively positioning the ethos, with identifications and struggles. 


\section{Identifying with Journalism}

Taking only the texts into consideration, we can say that out of the 73 mapped initiatives, 37 identified more strongly with journalism, with expressions being used like "journalism" or "journalist" to explain belonging to this field of production. However, 12 of the initiatives not identified as journalistic constitute markers of journalistic praxis - given there is also some sign of being connected to the field - by registering words like "stories", "interviews", "magazine", "agenda", and "material". These 12 initiatives are Candeia, Formiga.me, Las Abuelitas, Migramundo, Move that Jukebox, Mulher no Cinema, Ovelha Mag, Portal Aprendiz, Porvir, Revista Capitolina, Revista Paralela and Vaidapé. One example of this is an excerpt taken from Capitolina: "It is an independent online magazine for teenage girls. [...] Every month we choose the topic for our main material. Additionally, we run daily columns on more diverse areas of interest" (emphasis added).

There is a multiplicity of meanings among the 37 journalistic initiatives that seek to qualify/differentiate their respective practices and notions of journalism in the texts. There is attention drawn to a set of enunciations that are strong enough to clearly mark a position of opposition in relation to the journalism of large media and/or market reasons.

For instance, notions like "criticism" and "opposition" come up in some of the enunciations included in the arrangements. "Criticism" is made on "political, economic and social happenings" (Correio da Cidadania), which is a critical view of the facts with a "critical and alternative form of journalism different from that of large media conglomerates" ( $O$ Independente) which questions media conglomerates. "Opposition" has a few dimensions. One is the editorial which serves as opposition to "the editorial uniformity of large media" (Correio da Cidadania), in the sense that it "gives visibility to issues that end up being cast aside by commercial media" (Ponte). This "visibility" is in opposition to what gets "silenced" or "hidden" by commercial media. "Vozes da Vila Prudente" talks about the reality of the city's surrounding area from an alternative perspective, different from the narrative offered by "conventional media" which tends to be "generally negative and superficial". Another dimension of opposition is economy; a kind of media that does not receive "money from advertisers and their economic interests" (Correio da Cidadania) and that maintains "absolute editorial independence" ( $O$ Independente). 
The third dimension is the opposition to the structure of large media, something which is more clearly demonstrated in texts from Jornalistas Livres, with wording that narrates, on a macro level, the editorial/ideological issue as well as the economic one. "Tactics from the traditional journalistic industry", "business and ideological, commercial and private, corporate and corporatist interests", "centralizing and centralized media" are all examples of a few of the expressions used. The place of enunciation for the collective is marked by an opposition between large media and the work of Jornalistas Livres who express "an intense love for democracy and a commitment to the defense of human rights".

Some of the 37 initiatives in this study view journalism as being completely political, claiming it has the role of intervening in reality. A practice which is guided by an ideal, by a commitment to social change, and defends certain causes and political views uses a modern "romantic" ethos (Abreu, 1998) to identify the activity as a mission, as an action for political change. Some of the expressions from the texts reinforce this idea and asserts that production outside of large media is now possible, and the principles that come with this ethos, different from traditional newsrooms, can be achieved: "Our desire to register reality mirrors our desire to change it. Causes and actions are what interest us" (Fluxo); "our agenda is where social struggle and the articulation for cultural, political, economic and environmental changes are expressed" (Mídia Ninja).

Other initiatives, in opposition, act more as qualifiers and try to build a separate place of enunciation, one which invokes principles like impartiality, transparency, exemption, precision, and balance between conflicting parties. These are precepts connected to the constitution of a professional ethos for journalists from the twentieth century (Traquina, 2013), to the emergence of the "paradigm of information journalism" 3 (Charron \& de Bonville, 2016) and to a mode of press production anchored in commercial and business. It is no coincidence that they are strengthened by large journalistic companies as a form of legitimizing its place in the social world and the autonomy of journalism in relation to other social fields, like politics, which it was originally connected to (Barbosa, 2007).

Looking at the notion of distancing, this set of enunciations reflects signs that explicitly relate journalism to change or to a counter-hegemonic alternative, as in the following excerpt: 
[...] our journalists seek to support all our classification in a clear, objective and transparent way. [...] Our team is not militant nor do they express preferences - they are interested in listening to all sides. Any behavior that conflicts with the search for impartiality and plurality is not a part of the philosophy here at Aos Fatos, nor is it a part of our editorial line. (Aos Fatos).

These meanings disputed in enunciations (Maingueneau, 2008) around the notion of journalism sometimes relate journalism with activism. We can see examples of these kinds of meanings from media vehicles such as Geni, Aos Fatos and Fluxo. The ethos of Geni is "a magazine committed to libertarian values and to being activist - to serving activism". While Geni is close to activism but not the expression "journalism", Fluxo conflates "journalism" with "activism" and "politics": "to do journalism is to do politics. It means recognizing that activism does not contaminate our trade". Conversely, the ethos of Aos Fatos discursively relates journalism with activism: "they are neither activist nor do they express preferences".

While notions of plurality and impartiality are valued in the text from Aos Fatos, media vehicle Megafonia believes this place of enunciation reinforces a "position of media authority" and needs to be broken down in order to value narratives that consider "the complexity that exists in social struggles and on the streets" instead of using "impartiality masqueraded as news". However, aside from these clearly defined positions of politically-focused journalism and informative/distanced journalism there are cases where texts from this study build zones of intermediary meanings which value social actions that support particular causes and the "rigor of verifying facts" (Pública), "registering reality" (Fluxo), and "the real and verified truth" (Conexão Planeta). The value "of information that is true, of quality, checked and contextualized" and how "data and evidence" are treated and released is qualified by the magazine Gênero e Número as a form of drawing attention to journalism's contribution "to debates in society and the struggles fought on the streets and across networks".

Reporting and its respective qualifiers - "breathtaking stories" (Pública), "huge stories" (Puntero Izquierdo), "in-depth special reports" (Opera Mundi), and "journalism founded on reporting" (Farofafá) - is triggered by initiatives that legitimize the quality of the journalism being practiced. It shows the symbolic place of enunciation of this genre's prestige (and of the journalist who speaks through it) as a form of discourse historically associated, in Brazil, to building legitimacy in journalism as a specific field of production. "Pública believes in 
reporting and in the reporter" (Pública). "We produce REPORTS. We regret how the media industry has degraded the most honorable of journalistic genres and we are working to reduce this imbalance" (Jornalistas Livres).

The notion of independence (editorial/financial) also appears in enunciations from a number of initiatives trying to qualify the nature of its production notwithstanding the differences in proposals and their discursive efforts to distance themselves further from or closer to commercial and economic interests (Agência Pública, Correio da Cidadania, Fluxo, Gênero e Número, O Independente, Nexo, Mídia Ninja, Pressenza, Geni, Volt Data Lab). The names of two media vehicles from the analyzed corpus express independence in their titles even though they have distinctly different views of journalism; they are $O$ Independente and Mídia Ninja (Independent Journalism and Action Narratives).

Building a view of the surrounding area reveals how a distinct enunciation marks the ethos of media vehicles like "Agência Mural de Periferias", "Desenrola e Não Me Enrola", "Énois", "Vozes da Vila Prudente", and "Periferia em Movimento". Changing how the subjects "relate to the area they live in" (Agência Mural de Jornalismo das Periferias), creating "empowered and strong citizenship" (Vozes da Vila Prudente), informing about "sociocultural facts that occur in the surrounding area of São Paulo" from a "positive viewpoint" (Desenrola e Não Me Enrola), "report on events from our viewpoint" (Énois) are some of the meanings circulating in the texts of these vehicles which produce news from a specific "territory" (Periferia em Movimento), albeit with subtle differences. The theme of the genre is the production center of three media vehicles which express identification/belonging with journalism; they are Geni, AzMina and Gênero e Número. Even though they all have similar political agendas, there are significant differences in how they qualify their journalism from a more right-wing, distant or varied expression of activism, as we explained previously.

The name "new journalism" also appears in a number of texts that qualify/legitimize their respective ethos and differentiate it from "other journalisms". Expressions like "new", "trailblazer", "unique", and "original" are some of the distinct and relational enunciation strategies used by subjects to define a position which is symbolically advantageous in the production field, like carriers of change who announce the arrival of other models. Opera Mundi, 
for instance, establishes its ethos through a "single project model" capable of providing "a new view of the facts". Agência Publica considers itself a "trailblazer", Outras Palavras advertises a "new shared and collaborative journalism" while Nexo is committed to offering its readers an "original approach". Megafonia defines its preference for developing "a new journalism" remote from the value of impartiality while Fluxo defines itself as a "territory where reporters, cinematographers, photographers, editors and artists can explore new possibilities for journalism". Another important example is with Agência Democratize which has an ambitious motto of "overcoming existing models" which is neither a "business format" nor a "collective" one - discursively building a "third approach" to journalism. This vehicle's ethos is supported by the unique qualifier of "we think differently", as described in the following excerpt:

\begin{abstract}
Formed in August 2015, the Democratize Agency was created with the goal of establishing a third approach to journalism. But what is this? A third approach to journalism is not just about rejecting, but overcoming current models. This means not adhering to the business format of corporate journalism where information is filtered through the interests of a small number of families, making access to quality and truthful content impossible for most Brazilians. But it also does not adhere to the collective format because for alternative journalism to compete with with corporate and anti-democratic media it cannot just continue to follow the same content production model of "doing the opposite" or having a left-wing bias. You need to think differently. That is what we do: we think differently. (Democratize).
\end{abstract}

The expression "professional journalism" did not appear in the corpus texts which tentatively suggests that contemporary use of this qualifier as a distinct strategy is more valued by journalistic companies (Oliveira, 2016) than these new productive arrangements, taking into consideration the "classification struggles" (Bourdieu, 1996) that run through the field of journalism. It is important, however, to mention that both Agência Plano (a network of LatinAmerican journalists and photographers) and Agência Pública both use the expression "professionals" to refer to its group members. Furthermore, we have the example of Opera Mundi which highlights the presence of "journalists with tickets to important communication vehicles" (such as Folha de S.Paulo, O Estado de S. Paulo, Jornal do Brasil, Editora Abril) and mobilizes, to a certain degree, the symbolic capital of journalists, associated to professional careers in large media vehicles as a form of legitimization in the field. 


\section{Other places of enunciation}

The 36 initiatives which do not explicitly identify/belong to journalism in the texts show a complex mosaic of enunciations which we took out of the three main dimensions. On one side, there are "content producers" with enunciations like "a voice of authority on creativity and innovation" (B9), "content that inspires and proposes" (Brasis), "cover the growth of disruptive innovation" (Projeto Draft), "a magazine of good taste that adds values to ITS MARK, PRODUCT and SERVICE" (Revista Paralelo), and "producing 'genuine content" (Papo de Homem). These discursive forms use a grammar of the "new morphology of work" (Antunes, 2013) like signs of a learning and innovative spirit. Expressions like "creativity", "innovation", and "commitment" make up part of this discursive universe. The issue of commitment, central to current marks (Grohmann, 2017a) and added to the enunciation "adds values to its mark, product and service", indicates the idea of "content production" is aligned with hegemonic presuppositions of communication. It is important to point out how the ethos expressed through this place of enunciation also establishes dialogic relations with "inspirational narratives" based on "this capitalist logic of managing and producing goods, as well as inserting these goods into a market of ideas" (Casaqui, 2016, p. 4). By this we mean content production that should "innovate", "engage" and "inspire" while mobilizing attachments (Illouz, 2011) to the marks.

Other initiatives have their ethos in the democratization of communication. Their enunciations do not use the expression "journalism", instead they prefer "media" or "communication" like in the following examples: "alternative, community and public media" (Barão de Itararê), "a network of independent media producers" (Centro de Mídia Independente), "shared communication" and "independent writers and media" (Ciranda Internacional da Comunicação Independente). These initiatives mark their distinct journalistic ethos by not enunciating as a form of showing that the struggle for the democratization of communication is not restricted to borderline journalistic activities. The expressions "network" and "shared" also represent a more collective form of these vehicles' production. We also noted the presence of the words "alternative" (in one of the texts) and "independent" (included in the name of two initiatives) without any apparent differences in their discursive use.

There are places of enunciation that follow political identityagendas and social and educative projects which do not have any discursive link to journalism or defend the democratization of communication. Here, the 
communication/media is like a "medium" for the initiative's main objective, like an "NGO dedicated to empowering women through information" (Think Olga), or "content producers whose goal is to empower women" (Lado $M)$. Lastly, there are ten arrangements from the sample set that combine journalistic activities with other activities, which is discursively conveyed by the presence of journalism qualifiers (described in the previous section) and other kinds of qualifiers. For some of these initiatives, journalism qualifiers are related to the global action and change: "journalism and education to improve the world, especially for us women" (AzMina), "our desire to register reality mirrors our desire to change it" (Fluxo). These qualifiers are also related to values of collaboration, sharing (Outras Palavras) and community journalism (Desenrola e Não Enrola). The text from Énois, for instance, has elements similar to those in the previously mentioned texts (for example, the notion of "journalistic production [...] decentralized"), as well as enunciative marks from arrangements that speak about "innovation" and "quality" like in "innovation and diversity for journalism" and "quality journalistic production".

Other qualifiers get attached to these journalism qualifiers. Some of them refer to activities realized by the arrangements such as "consultations, talks and discussions" (AzMina), "products of communication, campaigns, methodologies, content distribution strategies, and youth mobilization" (Énois). These two cases show us how other "products", even when a journalism qualifier of social change is used, relate, to a certain degree, to "entrepreneurial journalism" (Grohmann \& Roxo, 2015).

Out of the ten projects, four of them express journalism and education but from different points of view. AzMina looks at "journalism and education" as a genre, both in its magazine and in other activities it develops. Desenrola e Não Enrola describes itself as a "educommunication project" (which also does community and cultural journalism). Centro de Estudos Barão de Itararé describes itself as a space for "shaping new communicators". Outras Palavras, despite having ties to "independent media, alternative communication and midialivrismo", calls itself a "Free School of Shared Communication". Énois also describes itself as a school, but of journalism, with a place of enunciation which is less about midialivrismo, shared communication or educommunication and more about "products and strategies for content distribution and mobilization".

Looking at this multiplicity of enunciations and diversity of identity we are able to recognize the difficulty of situating these initiatives' different places of enunciation and the disputes of meaning that cross over into them, which cannot be reduced to classification struggles 
over the definition of journalism. Our goal with this article was to map a panorama of this multiplicity of places of enunciation, the presence/ absence of enunciation marks related to journalism and the distinct strategies developed within these spaces. We discovered that speaking in "arrangements alternative to media corporations" is not about dealing with a unidimensional object, on the contrary, the enunciations we analyzed showed different viewpoints, specific projects in journalism and society.

\section{Overview and discussions}

The following tables are overviews of the analysis, emphasizing the multiplicity of places of enunciation mapped out in the study:

Table 1 - Identifying with Journalism

\begin{tabular}{|c|c|c|}
\hline $\begin{array}{c}\text { Place of } \\
\text { Enunciation }\end{array}$ & A few examples & Qualifiers of journalism \\
\hline $\begin{array}{l}\text { Politically-focused } \\
\text { journalism }\end{array}$ & $\begin{array}{l}\text { Fluxo, Mídia Ninja, } \\
\text { Jornalistas Livres }\end{array}$ & $\begin{array}{l}\text { "causes and actions interest } \\
\text { us", "our agenda is where social } \\
\text { struggles [...] exist" }\end{array}$ \\
\hline $\begin{array}{l}\text { Ethos of informative } \\
\text { journalism }\end{array}$ & Aos Fatos & $\begin{array}{l}\text { "not militant nor does it express } \\
\text { preferences" }\end{array}$ \\
\hline Valuing reporting & $\begin{array}{l}\text { Pública, Fluxo, } \\
\text { Conexão Planeta, } \\
\text { Puntero Izquierdo, } \\
\text { Farofafá }\end{array}$ & $\begin{array}{l}\text { "rigor in verifying the facts", } \\
\text { "the real and verified truth", } \\
\text { "journalism founded in reporting", } \\
\text { "breathtaking reports" }\end{array}$ \\
\hline $\begin{array}{l}\text { Independence } \\
\text { (editorial/ } \\
\text { financial) }\end{array}$ & $\begin{array}{l}\text { Pública, Correio } \\
\text { da Cidadania, } \\
\text { Gênero e Número, } \\
\text { O Independente, } \\
\text { Nexo, Volt Data Lab }\end{array}$ & $\begin{array}{l}\text { "absolute editorial independence", } \\
\text { "Mídia Ninja (Independent } \\
\text { Journalism and Action Narratives)", } \\
\text { "non-profit journalism for } \\
\text { maintaining independence". }\end{array}$ \\
\hline $\begin{array}{l}\text { Looking at the } \\
\text { surrounding areas }\end{array}$ & $\begin{array}{l}\text { Agência Mural } \\
\text { de Jornalismo } \\
\text { das Periferias, } \\
\text { Desenrola e não } \\
\text { me enrola, Énois, } \\
\text { Vozes da Vila } \\
\text { Prudente }\end{array}$ & $\begin{array}{l}\text { Change the way objects } \\
\text { "relate to the area they live } \\
\text { in", create "empowering and } \\
\text { strong citizenship", inform on } \\
\text { "sociocultural facts that occur in } \\
\text { the surrounding areas of São Paulo" } \\
\text { with "a positive viewpoint", "report } \\
\text { on events from our viewpoint" }\end{array}$ \\
\hline "New" Journalism & $\begin{array}{c}\text { Opera Mundi, } \\
\text { Agência Pública, } \\
\text { Outras Palavras, } \\
\text { Nexo, Megafonia, } \\
\text { Agência } \\
\text { Democratize } \\
\end{array}$ & $\begin{array}{l}\text { "new", "trailblazer", "unique", } \\
\text { "original", "new shared and } \\
\text { collaborative journalism", } \\
\text { "original approach", "new } \\
\text { possibilities for journalism", } \\
\text { "overcoming existing models" }\end{array}$ \\
\hline
\end{tabular}

Source: prepared by authors 
Table 2 - Other places of enunciation

\begin{tabular}{|c|c|c|}
\hline $\begin{array}{c}\text { Place of } \\
\text { Enunciation }\end{array}$ & A few examples & Qualifiers \\
\hline $\begin{array}{l}\text { Content } \\
\text { producers }\end{array}$ & $\begin{array}{l}\text { B9, Brasis, Projeto } \\
\text { Draft, Revista } \\
\text { Paralelo, Papo de } \\
\text { Homem }\end{array}$ & $\begin{array}{l}\text { "a voice of authority on } \\
\text { creativity and innovation", } \\
\text { "content that inspires and } \\
\text { proposes", "a magazine of good } \\
\text { taste that adds value to ITS } \\
\text { MARK, PRODUCT and SERVICE", } \\
\text { "producing genuine content" }\end{array}$ \\
\hline $\begin{array}{c}\text { Democratization } \\
\text { of } \\
\text { communication }\end{array}$ & $\begin{array}{c}\text { Barão de Itararé, } \\
\text { Centro de Mídia } \\
\text { Independente, } \\
\text { Ciranda } \\
\text { Internacional }\end{array}$ & $\begin{array}{l}\text { "network", "shared", } \\
\text { "alternative, community and } \\
\text { public media", "a network of } \\
\text { independent media producers" }\end{array}$ \\
\hline $\begin{array}{l}\text { Political and/ } \\
\text { or educational } \\
\text { agendas }\end{array}$ & $\begin{array}{l}\text { Think Olga, } \\
\text { Lado M, AzMina, } \\
\text { Desenrola e Não } \\
\text { Enrola, ÉNois }\end{array}$ & $\begin{array}{l}\text { "empowering women through } \\
\text { information", "content producers } \\
\text { whose goal is to empower } \\
\text { women", "journalism and } \\
\text { education to improve the world" }\end{array}$ \\
\hline
\end{tabular}

Source: prepared by authors

Classifying and categorizing are methodological challenges that come with researching. On one hand, categorizations cannot be closed off or crystallized because there are a number of positions within each category (which we presented in this text). On the other hand, these classifications gave us clues and indicators to explore our object of study. Inside these "classification struggles" (Bourdieu, 1996), discursively fought within the alternative economic arrangements, there are "external" distinctions for explaining the differences between "large media" journalism and "traditional" journalism. There are also "internal" distinctions which can be translated in the more varied places of enunciation listed above, as well as create tensions around the expression "journalism" itself.

Yet the places of enunciation also reveal important identifications. There are different relationships with the deontology of journalism with the word "independent" restating the importance of journalistic discourse being different from the establishment, and values of impartiality, objectivity and a commitment to registering reality. Here you can see the effects of hegemonic approximation (and not just distancing) to use journalism and the enunciative strategies mobilized by large media to legitimize its place in the professional field.

Journalism as a form for changing social reality is somewhat recovered and given new meaning by some initiatives, 
whether through political identity or educational agendas, the democratization of journalism, looking at surrounding areas or dialoguing with politically engaged journalism which evokes notions like cause, mission and activism. Here you can see the tension between the discourses of "technical" journalism distanced from social contradictions when stating the legitimacy of an activity with a specific commitment to certain political struggles. However, matching the notion of engagement/activism with deontological precepts and knowledge is consolidated in the professional field, such as valuing reporting and the rigor of verifying facts.

How do these different places of enunciation relate to the dynamics of journalism? In a way, these places dispute classification and distinction (Bourdieu, 1996; 2007), and renew or update current approaches and perspectives in the field. For example, the ethos of "politically engaged journalism", "informative journalism" and "valuing reporting" are not born in new alternative arrangements, but are historically marked in the professional field. The initiatives studied for this paper show these places in the field are updated through enunciations.

The same can be said about the ethos of "democratization of communication", which is politically engaged but also rejects the expression "journalism". The initiatives related to this ethos are older than most of the arrangements (which emerged mainly after 2013), marked by the increase of global social forums at the turn of the century (CMI is from 1999 and Ciranda is from 2001), and with subjects who have been more active in the profession (like Altamiro Borges from Barão de Itararé). It is an ethos that approaches activism without establishing its professional journalistic identity.

While some places of enunciation point towards updating current approaches and perspectives in the field, others indicate deeper displacements and changes that redefine/tension the limits of journalism. One example is the ethos of content producers which is associated to the grammar of entrepreneurship and capital which advances in the contemporary world following the rationality of the neoliberal system (Dardot \& Laval, 2016). This ethos is influenced by external forces - from areas like administration, management and business - focusing on journalism (Carbasse, 2015) as a narrative ("innovation", "creativity", "added value") and also as a way to perceive journalistic activity (business models, company journalist).

While the places of enunciation mapped out in this stage of the study relate to the specific characteristics of internal struggles that move 
journalism as a field of production, they also represent huge changes in the work world in terms of use and mobilization of production efforts, as well as the presence of technological power that redefines how contemporary journalism is done - this helped us to see the broader design of collective research which is explored as our knowledge about the dynamics of these new arrangements continues to grow.

\section{NOTES}

1 One of the objectives of the study is to define what alternative arrangements to media corporations are.

2 According to the analysis of the literary field in his book As Regras da Arte (1996).

3 In the typology presented by these French authors, this model is developed in contrast to the "opinion journalism" characteristic of the twentieth century and strongly linked to political struggles. From a positivist point of view (which indicates the neutrality of facts) information journalism "serves reality" and is anchored in values and rules that "value the standard elements of information" (Charron \& de Bonville, 2016, p. 198 e 254). In Brazil, there are other authors who focus on how journalism is practiced and conceived within this displacement, characterized by the transition in the twentieth century from a politicaly affiliated press to a business model of the press which is anchored in the paradigm of information based on facts. (Sodré, 1977; Barbosa, 2007; Ribeiro, 2003). This displacement occurs within the context of broader structural changes to the development of urban-industrial societies.

\section{REFERENCES}

Abreu, A. (1998) Jornalistas: de românticos a profissionais. Antropolítica, 5 (2), pp. 7-19.

Antunes, R. (2013). A nova morfologia do trabalho e suas principais tendências. In R. Antunes (Ed.). Riqueza e Miséria do Trabalho no Brasil II (pp. 13-28). São Paulo: Boitempo.

Aristóteles. (1998). Arte Retórica e Arte Poética. São Paulo: Ediouro.

Assis, E. et al. (2017). Autonomia, ativismo e colaboração: contribuições 
para o debate sobre a mídia independente contemporânea. Pauta Geral. 4 (1), pp. 3-20. Retrived from www.revistas2.uepg.br/index. php/pauta/article/view/9899

Baccega, M. (1995). Palavra e Discurso. São Paulo: Ática.

Baccega, M. (1998). Comunicação e Linguagem. São Paulo: Moderna.

Barbosa, M. (2007). História Cultural da Imprensa: Brasil, 1900-2000. Rio de Janeiro: Mauad X.

Bakhtin, M. (2003). Estética da Criação Verbal. São Paulo: Martins Fontes.

Bakhtin, M. (2010) Marxismo e Filosofia da Linguagem. São Paulo: Hucitec.

Baldin, N. \& Munhoz, E. (2011) Snowball (bola de neve): uma técnica metodológica para pesquisa em educação ambiental comunitária. In: X Congresso Nacional de Educação - EDUCERE. Curitiba/PR, pp. 329341. Retrived from educere.bruc.com.br/CD2011/pdf/4398_2342.pdf

Barthes, R. (2001). A Aventura Semiológica. São Paulo: Martins Fontes.

Bourdieu, P. (1996). As Regras da Arte: gênese e estrutura do campo literário. São Paulo: Companhia das Letras,

Bourdieu, P. (2007). A Distinção. São Paulo: Edusp.

Bourdieu, P. (2008) A Economia das Trocas Linguísticas. São Paulo: Edusp.

Carbasse, R. (2015). Tinos para os negócios e bom jornalismo? A figura do jornalista empreendedor nos debates sobre o futuro da profissão. Brazilian Journalism Research 11 (1), pp. 262-283. doi. org/10.25200/BJR.v11n1.2015.591

Carvalho, G. \& Bronosky, M. (2017). Jornalismo Alternativo no Brasil: do impresso ao digital. Pauta Geral. 4 (1), pp. 21-39. Retrived from www.revistas2.uepg.br/index.php/pauta/article/view/10007

Casaqui, V. (2016). A Inspiração como Forma Comunicacional do Capitalismo Cool. Congresso Brasileiro de Ciências da Comunicação (Intercom). São Paulo/SP: ECA-USP. Retrived from portalintercom.org. br/anais/nacional2016/resumos/R11-0837-1.pdf

Charron, J. \& de Bonville, J. (2016). Natureza e Transformação do Jornalismo. Florianópolis: Insular.

Dardot, P. \& Laval, C. (2016). A Nova Razão do Mundo. São Paulo: Boitempo.

Ducrot, O. \& Todorov, T. (1988) Dicionário Enciclopédico das Ciências da Linguagem. São Paulo: Perspectiva. 
Fairclough, N. (2008) Discurso e Mudança Social. Brasilia: Ed. UnB.

Figaro, R. (2014). O campo da comunicação e a atividade linguageira no mundo do trabalho. Chasqui. 126, pp. 57-65. dx.doi.org/10.16921/ chasqui.v0i126.266

Figaro, R. \& Nonato, C. (2017). Novos "Arranjos Econômicos" Alternativos para a Produção Jornalística. Contemporânea. 15 (1), pp. 47-63. dx.doi.org/10.9771/1809-9386contemporanea.v15i1.21451

Figaro, R., Nonato, C. \& Grohmann, R. (2013). As Mudanças no Mundo do Trabalho do Jornalista. São Paulo: Atlas.

Figaro, R., Nonato, C. \& Kinoshita, J. (2017). Jornalistas em arranjos econômicos independentes de corporações de mídia: métodos e análises iniciais. Congresso Brasileiro de Ciências da Comunicação (Intercom). Curitiba (PR). Retrived from portalintercom.org.br/anais/ nacional2017/resumos/R12-0420-1.pdf

Fiorin, J. (1994). Polifonia Textual e Discursiva. In: D. Barros \& J. Fiorin (Eds.). Dialogismo, Polifonia, Intertextualidade (pp. 29-36). São Paulo: Edusp.

Fiorin,J. (2004). O Pathos do Enunciatário. Alfa.48(2), pp. 69-78. Retrived from periodicos.fclar.unesp.br/alfa/article/download/4297/3885

Grohmann, R. (2017a) A Noção de Engajamento: sentidos e armadilhas para os estudos de recepção. Encontro Anual da Compós. São Paulo/SP: Cásper Líbero. Retrived from www.compo s.org.br/data/ arquivos_2017/ trabalhos_ar quivo_7G E76QSBYJXKK26A2HDW_26_ 5189_17_02_2017_21_52_18.pdf

Grohmann, R. (2017b). Inovação como Fórmula Discursiva Convocatória para as Práticas Jornalísticas: sentidos mobilizados por textos do Observatório da Imprensa. Contemporânea. 15 (1), pp. 207226. dx.doi.org/10.9771/1809-9386contemporanea.v15i1.20646

Grohmann, R \& Roxo, M. (2015). Os discursos sobre o jornalistaempreendedor em sites especializados na cobertura do campo profissional. Contemporânea. 13 (2), pp. 471-486. dx.doi. org/10.9771/1809-9386contemporanea.v13i2.13524

Illouz, E. (2011). O Amor nos Tempos de Capitalismo. Rio de Janeiro: Zahar.

Maingueneau, D. (2008). Análise de Textos de Comunicação. São Paulo: Cortez.

Mick, J. \& Lima, S. (2013). Perfil do Jornalista Brasileiro. Florianópolis: Insular.

Nagamine, H. (2012). Conceitos e fundamentos: enunciação e construção do sentido. In R. Figaro (Ed.). Comunicação e Análise do 
Discurso (pp. 19-43). São Paulo: Contexto.

Nouroudine, A. (2002). A linguagem: dispositivo revelador da complexidade do trabalho. In M. Souza-e-Silva \& D. Fäita (Eds.). Linguagem e Trabalho (pp. 17-30). São Paulo: Cortez.

Oliveira, M. R. (2005). Profissão Jornalista: um estudo sobre representações sociais, identidade profissional e as condições de produção da notícia (Dissertação de Mestrado). Retrived from www.faac.unesp.br/Home/Pos-Graduacao/Comunicacao/Disserta coesDefendidas/michelleroxo.pdf

Oliveira, M. R. (2016) O Jornalismo Profissional e suas Fronteiras: estratégia de distinção de um jornal-empresa a partir da emergência de novos meios e processos de produção. Congresso Brasileiro de Ciências da Comunicação (Intercom). São Paulo/SP: ECA-USP. Retrived from portalintercom.org.br/anais/nacional2016/resumos/R1 1-1952-1.pdf

Peruzzo, C. (2013). Movimentos Sociais, Redes Virtuais e Mídia Alternativa no Junho em que "o gigante acordou" (?). MATRIZes. 7 (2), pp. 73-93. doi.org/10.11606/issn.1982-8160.v7i2p73-93

Pública, Agência. (2017). O mapa do jornalismo independente. Retrived from apublica.org/mapa-do-jornalismo/

Ramos, D. \& Spinelli, E. (2015.) Iniciativas do Jornalismo Independente no Brasil e Argentina. Extraprensa (USP). 9 (17), 114-123. doi. org/10.11606/extraprensa2015.104463

Reis, M. (2017). Comunicar, Resistir: um olhar sobre as práticas discursivas em rede do jornalismo independente no Brasil. Vozes \& Diálogo. 16 (1), pp. 193-204. Retrived from siaiap32.univali.br/seer/ index.php/vd/article/view/9455

Ribeiro, A. P. (2003) Jornalismo, literatura e política: a modernização da imprensa carioca nos anos 1950. Estudos Históricos. Rio de Janeiro, 31, pp. 147-160.

Sodré, N. W. (1977). História da Imprensa no Brasil (2nd ed). Rio de Janeiro: Edições do Graal.

Suzigan, W. et al. (2004). Clusters ou sistemas locais de produção: mapeamento, tipologia e sugestões de políticas. Revista de Economia Política. 24 (4), pp. 543-562. Retrived from www.rep.org.br/PDF/96-6.PDF

Traquina, N. (2013). Teorias do Jornalismo: a tribo jornalística - uma comunidade interpretativa transnacional. Florianópolis: Insular.

Waltz, I. (2017). Mídia NINJA e o ethos profissional dos jornalistas: a ascensão da mídia livre sob a ótica da redação dos veículos de massa. Mediação. 19 (24), pp. 215-237. Retrived from www.fumec. $\mathrm{br} / \mathrm{revistas/mediacao/article/view/4770}$ 
RAFAEL GROHMANN. Postdoctoral researcher of Universidade Federal do Rio de Janeiro (UFRJ). He has a PhD in Communication from the University of São Paulo (ECA-USP). He is a member of the Communication and Work Research Center (CPCT/ ECA-USP). E-mail: rafael-ng@uol.com.br.

Design, planning, collection and interpretation of data, writing and critical review of article.

MICHELLE ROXO. Professor of the Master's Degree course in Professional Journalism at FIAM-FAAM - University Center. She has a PhD in Communication from Fluminense Federal University (UFF). She is a member of the Communication and Work Research Center (CPCT/ ECA-USP) E-mail: michelle_roxo@yahoo.com.br Design, planning, collection and interpretation of data, writing and critical review of article.

ANA FLÁVIA MARQUES. Currently studying for her Master's Degree in Communication at the University of São Paulo (ECA-USP). She is a member of the Communication and Work Research Center (CPCT/ ECA-USP). E-mail: anaflaviamarx@gmail.com.

Design, planning, collection and interpretation of data.

TRANSLATED BY: LEE SHARP 